\title{
Evaluation of human impact on valley bottom sedimentation in Highlands: case study from Česká Bělá, Czechia
}

\author{
LENKA VEJROSTOVÁ ${ }^{1,2}$, LENKA LISÁ $^{3}$, ALEŠ BAJER $^{1}$, JAN PACINA $^{1}$
}

\footnotetext{
${ }^{1}$ Mendel University, Faculty of Forestry and Wood technology, Department of Geology and Pedology, Brno, Czechia; e-mail: vejrostova.lenka@gmail.com

${ }^{2}$ Charles University, Faculty of Science, Department of Physical Geography and Geoecology, Prague, Czechia

${ }^{3}$ Masaryk University, Faculty of Sciences, Department of Geological Sciences, Brno, Czechia; e-mail: lisa@gli.cas.cz
}

ABSTRACT The formation processes of small valleys and long-term anthropogenic impact on its sedimentary archives may be studied by GIS, sedimentology and investigation into spatial and vertical geochemical characteristics in the context of mining activities. The case study from the Bohemian-Moravian Highlands with well documented medieval mining activities demonstrates the typical dynamics of a small valley during the last centuries and also the possible rate of human impact. The information value of the floodplain record as well as the development of the landscape geomorphology is discussed. The infilling of the river bottom is comprised of two main lithological units keeping information about medieval mining and ore processing as well as about past and recent agricultural activities. The most recent land use influenced the aggradation of the valley bottom less than land use during the Medieval times.

KEY WORDS landscape evolution - environmental archives - floodplain deposits - medieval mining - Czechia

VEJRoSTOVÁ, L., LISÁ, L., BAJER, A., PACINA, J. (2017): Evaluation of human impact on valley bottom sedimentation in Highlands: case study from Česká Bělá, Czechia. Geografie, 122, 1, 21-44. Received January 2016, accepted October 2016. 


\section{Introduction}

Floodplains may be significant archives of an anthropogenic impact on landscape. One of the main reasons is their Holocene age and a dynamic development linked to an anthropogenic activity since prehistoric times. In the area of Czechia were, for example, well dated floodplain deposits of the Morava River which cover mainly last 1,000 years (Grygar et al. 2010), but anthropogenic impact on landscape is mostly believed to be dated back to the Neolithic revolution (Lüning, 1996, Williams 2003, Dotterweich 2008, Parma et al. 2015). What we lack is a deeper understanding of dynamics of small stream valleys in highland areas, past flood magnitude and frequency, especially in anthropogenic context. Papers on this subject usually deal with the settlement strategies, mining practices (Hrubý et al. 2014) or the rate of pollution (Horák, Hejcman 2013).

What exactly are the main factors influencing the formation processes of flood plains in small highland valleys? Slope processes are in this context believed to be mainly the evidence of anthropogenic impact, whereas fluvial sediments may gather information about the climate in general (Dotterweich 2008). Contrary to this, small catchments behave differently. Their low buffer capacity results in sensitivity to land use changes (Dearing, Jones, 2003) and population pressure (Dotterweich 2013). Alluviums deposited in the stream bottoms, if preserved, may become very detailed archive of human impact on the landscape. The land use may represent both agricultural practices and mining among others. Central European area had witnessed many phases of agricultural expansion and regression, as well as land use and land cover changes connected with these anthropogenic activities since Neolithic (Williams 2003, Dotterweich 2008). Agricultural practices had a great impact on landscape (Levin 2008, Dotterweich 2013). Other important processes are industrialisation and urbanisation, which are the second great drivers of catchment modification (Hoffmann et al. 2010). Anthropogenic activity therefore progressively became main driver of geomorphological change (Messerli et al. 2000).

Most of the information available regarding the development of Central European landscape morphology in context of fluvial formation processes comes from valleys of big rivers (Anderson, Anderson 2010; Mol, Vandenbergh, Kasse 2000). The reason is that the big river floodplain zones offer well interpretable sedimentological archives (Macklin et al. 2006) and might be usually discussed also in context of recent or past human impact (Macklin, Lewin, Jones 2014). On the other hand, there is a lack of information about the small stream valley morphology development from mid-latitudes, because of scarcity of well interpretable archives. What we already know about the human impact on the development of typical V-shape valleys of small streams in highlands? The appearance of these valleys is very common, but its environmental record is usually quite limited. 


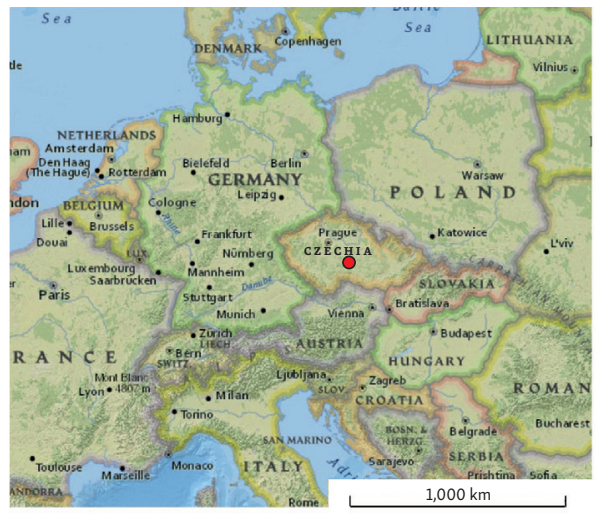

Fig. 1 - The location of Březina stream in a municipality of Česká Bělá, in the Moravian-Bohemian Highlands, Czechia; A - map of the Third Military Survey of the Habsburg Empire from 1877, B ortophotograph from 1953, C - ortophotograph from 2015.
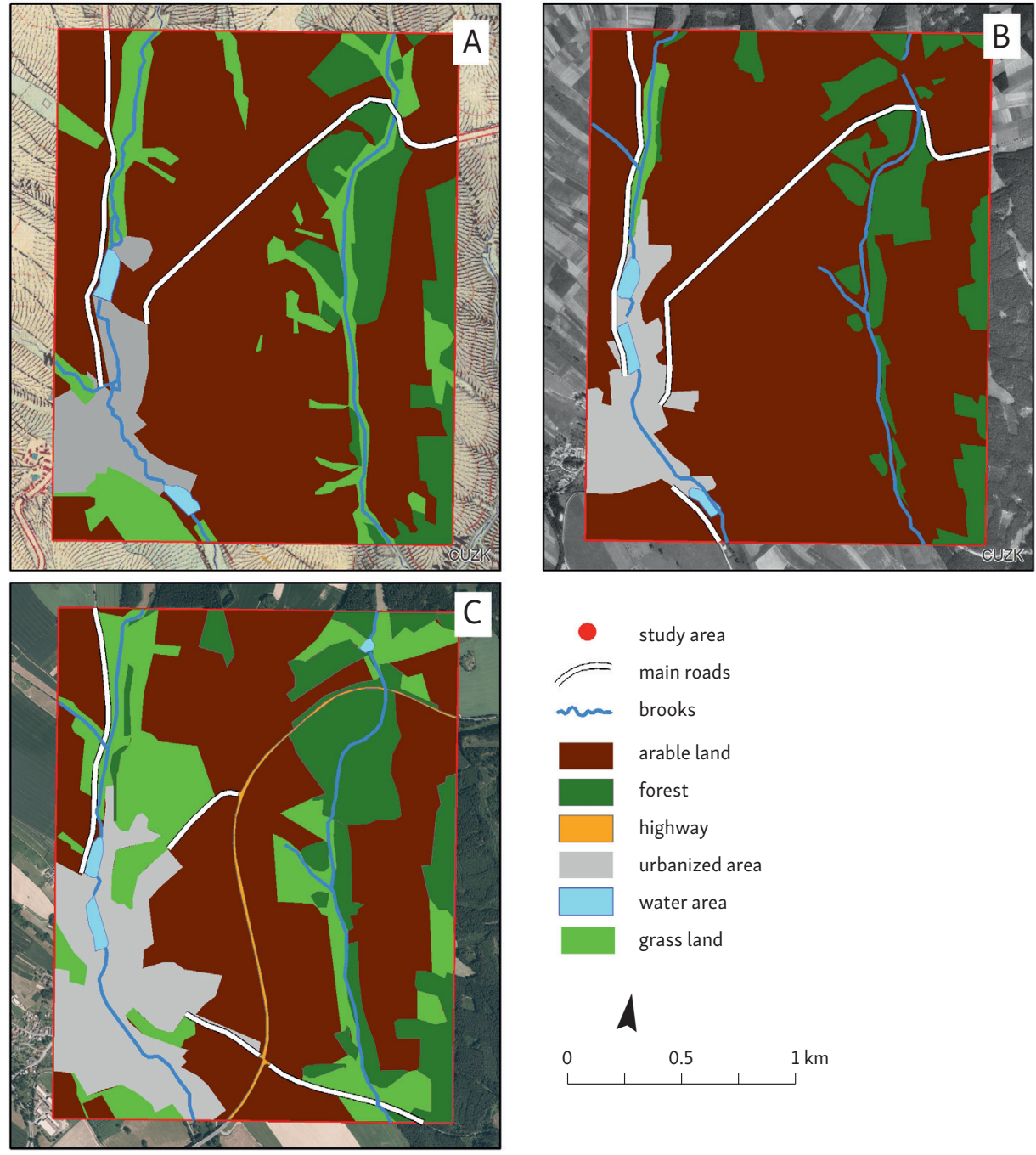

\section{study area}

$=$ main roads

brooks

arable land

forest

प highway

urbanized area

$\square$ water area

grass land

4

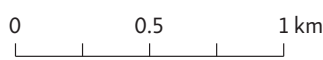


Some geomorphological studies are available from mountainous areas (e.g. Milliman, Syvitski 1992) as well as from lowlands (Kalicki, Nowak 2014), but such studies are rare in highland types of landscapes. The small stream function and contamination of floodplain in context of human impact in highlands are recently discussed for example by Kř́̌́žek (2007), Treml et al. (2008), Horák and Hejcman (2013), Nováková et al. (2015) or Matys Grygar et al. (2015). The information about the environmental record of the floodplain of small streams in the BohemianMoravian Highlands are very limited. In fact, there is only one paper available by Hrubý et al. (2014). It seems that localities published by Hrubý at al. (2014) have similar formation history as the site discussed in this paper.

One of the possibilities how to study the formation processes of floodplains located in highland areas in anthropogenic context, is to choose the area intensively influenced since the Middle Ages. We chose to study Březina stream valley near Česká Bělá in the Bohemian-Moravian Highlands, Czechia (Fig. 1) in detail. The Březina stream valley was selected for its suitable sedimentary record. We also decided to investigate morphometric parameters of a wider GIS testing area (approximately $100 \mathrm{~km}^{2}$ ) to find out whether Březina valley is a typical highland valley or not and what are the parameters of typical valley in this area. The mining activities within the study area are documented there since the Middle Ages. Recently, the area is agriculturally cultivated without any construction activities.

The research questions discussed in this paper are as follow: Does the chosen site represent typical example of highland valley? What are the most typical formation processes of floodplains and the role of colluvial deposition in highlands of Central Europe? How exactly is it possible to detect the intensity of past anthropogenic impact on landscape in these small catchments? Had the medieval activity more intensive impact on the valley morphology than recent agricultural processes?

\section{Overview of the study area}

The study area is represented by a small basin of Březina stream $\left(2.6 \mathrm{~km}^{2}\right)$ located in a municipality of Česká Bělá, in the Moravian-Bohemian Highlands, Czechia (Fig. 1). The stream's source (588 $\mathrm{m}$ a.s.l.) is located westwards from the Bída hill (606.4 $\mathrm{m}$ a.s.1.) and its length is $3.9 \mathrm{~km}$. The study area includes the first $2.9 \mathrm{~km}$ of the narrow floodplain (5-10 m wide, length in the study area: $2.25 \mathrm{~km}$ ). The part of the Březina stream included into this study is not affected by tributaries.

Basic information required for understanding the valley's development are of geological and geomorphological nature. The study area is located in the Crystalline Complex of Bohemian Massif. The valley's shape is more or less predisposed by lithology, because its two slopes are different from lithological point of view. The western slope is convex-concave and quite gentle and it is mostly made up of 


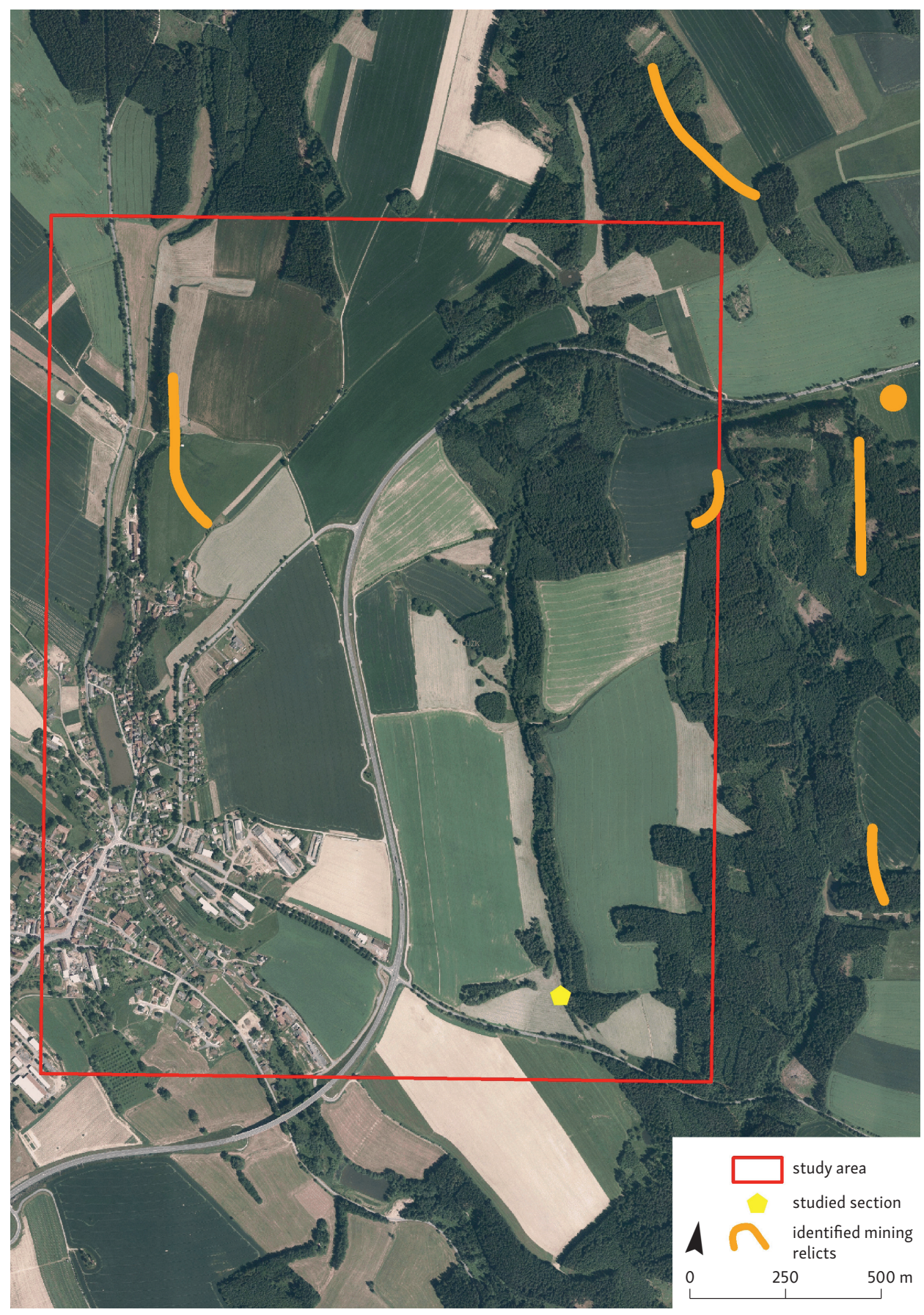

Fig. 2 - The study area with recorded mining relicts (dark yellow) and the position of the study section (light yellow). 
mica-schist, whereas the eastern slope is concave and much steeper and it is made up of paragneiss/migmatite (for slope inclination see Fig. 3). Česká Bělá area is the northernmost part of the Havlíčkův Brod mining area (Hrubý et al. 2014). The main reason why this area was mined during medieval times was the ore mineralization which occurs within vein quartz and breccia of Carboniferous origin. This probably disjointedly mineralized structure is about $7 \mathrm{~km}$ long. Pollymetallic sulphide mineralisation was identified as well as $\mathrm{Fe}-\mathrm{Zn}-\mathrm{Pb}$-Ag mineralisation. There is prevalence of sphalerite and pyrite, microscopic galena and arsenopyrite can be found as well. Hrubý et al. (2014) studied the archaeological and sedimentological evidence in this area and reported thick infilling of the valley bottom composed of organic clay material covered by silty to sandy material.

From archaeological and geomorphological point of view the most easily noticeable evidence of mining are mining pits. Those were dated back to the $13^{\text {th }}$ century thanks to the mining district analogy (Bernard 1991, Malý 1998). A diameter of the mining pits varies from 4 to 9 meters. The rest of mining objects are most likely prospection shafts. All these forms are located in the upper part of the valley. Besides the mining area, archaeologists were able to describe also the area of primary ore processing in the lower part of the valley (Hrubý et al. 2014). For exact position see Figure 2.

\section{Research materials and methods}

\subsection{GIS}

The general image of the typical highland valley morphometry was studied by the observation of the valley depth (Fig. 3) in the chosen area. This parameter was analysed using the elevation and hydrological GIS data of the region. The DIBAVOD dataset (Dibavod 2016) is the most complete database containing hydrological network of the Czechia, thus this dataset was suitable for this kind of analysis. The contour lines ( $5 \mathrm{~m}$ interval) from the Digital model of territory in scale 1:25,000 (maintained by the Czech army topographical service) were used as the source of elevation data. There are available more detailed data for the area of interest (LIDAR) but the algorithms for ridge detection requires smoothly interpolated Digital Terrain Model (DTM) and thus the $5 \mathrm{~m}$ interval contour lines are suitable enough for this purpose. The Topo to Raster interpolation method (ESRI 2012), implemented in ArcGIS was used as it produces hydrologically correct DTM. The streamlines taken from the DIBAVOD database were used within the interpolation as obligatory edges to preserve the shape of the valleys. The valley depth is a vertical distance $(\mathrm{m})$ between the valley floor and line joining the surrounding ridges (see Fig. 4). The ridge line delineation was performed using the $1^{\text {st }}$ and $2^{\text {nd }}$ 

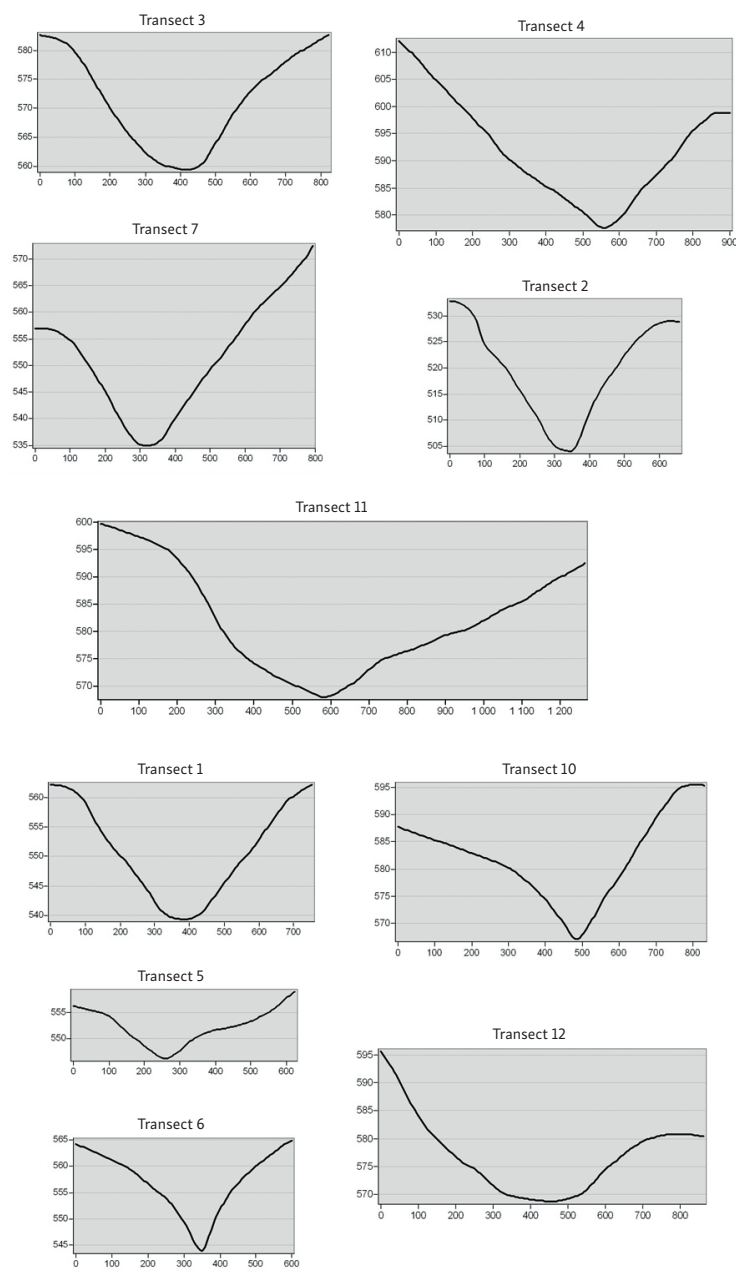

Transect 9
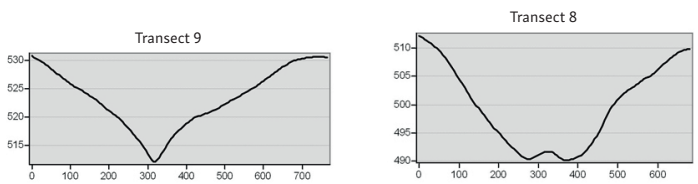
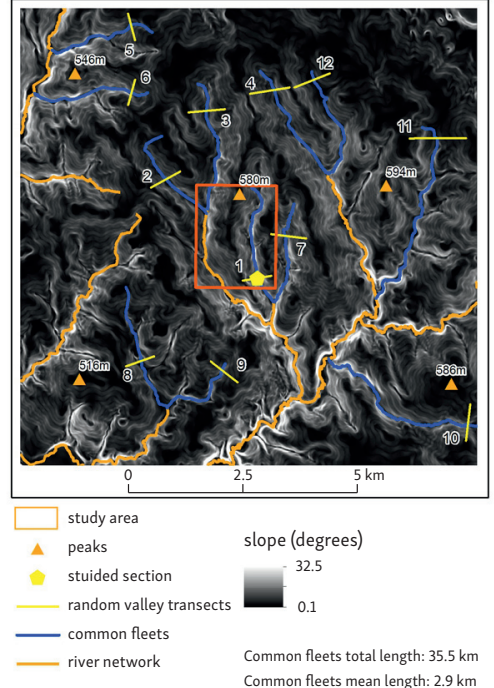
Common fleets mean length: $2.9 \mathrm{~km}$

Fig. 3 - The valley depth analysed within the area of 100 square kilometres using the elevation and hydrological GIS data (DIBAVOD dataset). The cross sections of small stream valleys are demonstrated to show how typical is the study valley.

order geomorphometric variables (slope, orientation, curvature) and algorithms described in Minár et al. (2013) and Jenčo, Pacina, Sharry (2009). The main task of these algorithms is to delineate the boundaries of elementary forms of georelief (and ridges are this type of boundary) - the principle is to search for local extremes within the computed datasets (derived morphometrical characteristics up to the $3^{\text {rd }}$ order) with the use of edge detectors. The algorithms were used because they are producing verified outputs in a reasonable time period. The valley 


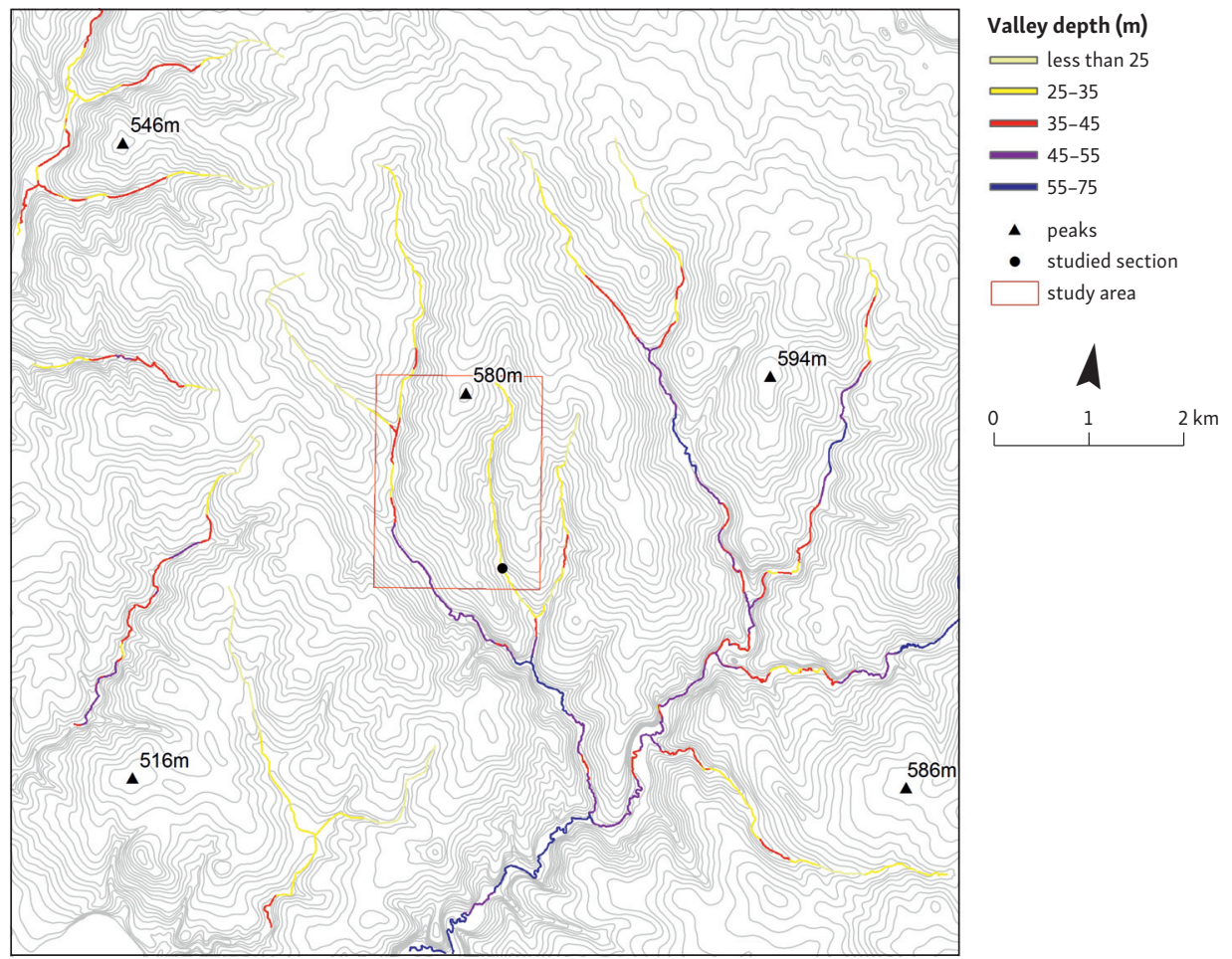

Fig. 4 - The valley depth was computed as the difference of the valley bottom and the line joining the surrounding ridges

depth computation was performed along the following scheme: The DTM was interpolated using the Topo to Raster interpolation method followed by the DTM quality estimation (visual comparison of the input contour lines and the contour lines derived from the resulting DTM with $2.5 \mathrm{~m}$ interval). The ridge detecting algorithms were used for ridge identification - the result is a GIS grid layer. The selected streamlines from the DIBAVOD database are converted into grid layer. The elevation from the interpolated DTM is assigned to each pixel of the identified ridge and converted streamline. The ridges are further converted to a vector layer and are used as the input data for Triangulated Irregular Network interpolation (TIN). The TIN interpolation based only on ridges secures the straight connection in-between the neighbouring ridges. The TIN is converted back to grid with a reasonable resolution ( $5 \mathrm{~m}$ in our case) and the difference of the streamline and the corresponding pixel of the "TIN-derived grid" is assumed to be the valley depth.

To understand the development of Březina valley, we studied maps of the First (2 sheets), the Second and the Third Military Survey of the Habsburg Empire and ortophotographs from the $20^{\text {th }}$ and the $21^{\text {st }}$ century (Fig. 1). The First Military 
Survey of this area was carried out between 1763 and 1768, the Second Military Survey was carried out in 1852 and the Third Military Survey was carried out in 1877. Further we analysed modern maps, aerial photographs and lidar-derived images. We mainly focused on morphology of the valley, the extent of floodplain, the role of colluvial deposition in formation of floodplain and the presence of anthropogenic features such as the relicts of mining, land use and land cover. The hand digitized land cover based on ortophoto $(1953,2014)$ and the $3^{\text {rd }}$ Military Survey of the Habsburg Empire is presented on figure 1. Five main categories were identified within the area of interest - arable land, forest, grass land, water bodies and urbanized area. The land cover reconstruction based on the 1953 ortophoto has only one area identified as grass land. This is possibly caused by the low distinguishing level in-between the arable land (field) and grass land on the archival aerial photographs.

\subsection{Sedimentology and micromorphology}

The thickness of sedimentary record along the stream varies from few centimetres to approximately 3 metres as confirmed during the recognoscation works. This corresponds with the findings of Hrubý et al. (2014). Generally, the sedimentological record observed along the stream banks and in detail checked on three sections and one core shows the continuity of main horizons. Therefore, only one, the best preserved, section was chosen for sampling (Fig. 2, 5 in detail). This section is comparable with the section examined by Hrubý et al. (2014; marked as P3 $-49^{\circ} 38^{\prime} 34.032 \mathrm{~N} 15^{\circ} 42^{\prime} 32.523 \mathrm{E}$ ). It is located at the lower part of the valley, on the right side of the Březina stream (western slope of the valley). The applied methodological tools included basic sedimentological description, colour identification according to Munsell color chart (Munsell 2000), micromorphological observation of the bottom part of sedimentary record, Mehlich III analyses, magnetic parameters and by OSL dating.

After the documentation, 32 bulk samples were taken for chemical analyses (sampling interval = each $10 \mathrm{~cm}$ in upper $60 \mathrm{~cm}$ of section and each $5 \mathrm{~cm}$ within the rest of the section depending on the material sampled) as well as 3 micromorphological samples in the dimension of $3 \times 4 \mathrm{~cm}$ from the depths of $60 \mathrm{~cm}$, $120 \mathrm{~cm}$ and $170 \mathrm{~cm}$ (see Fig. 5). All the samples were taken into small paper Kubiena boxes, dried and impregnated by Polyllite 2000 resin and then thin sectioned in the laboratory of the Institute of Geology ASCR, v. v. i. The standard protocol after Stoops (2003) was used for the preparation and the description. 


\subsection{Geochemistry and magnetic parameters}

The concentrations of all plant-available elements (P, K, Ca, $\mathrm{Mg}, \mathrm{Zn}, \mathrm{Cu}, \mathrm{Cd}$ and $\mathrm{Pb}$ ) were determined in a M3 (Mehlich III) solution by inductively-coupled plasma optical emission spectrometry. The results were given in units of mg leached from $1 \mathrm{~kg}$ of sediment of sample by the M3 process. Magnetic susceptibility was measured using an Agico MFK1-FA Kappabridge at two different operating frequencies, $\mathrm{fl}=976 \mathrm{~Hz}$ and $\mathrm{f} 3=15,616 \mathrm{~Hz}$, amplitude of AC field was $200 \mathrm{~A} / \mathrm{m}$ (peak value). Readings of the unconsolidated samples were taken in plastic bags. The measured susceptibility values were normalized by the mass of each sample and expressed as mass susceptibility $\left[\mathrm{m}^{3} \cdot \mathrm{kg}^{-1}\right]$. Frequency dependent magnetic susceptibility, $\mathrm{kFD}$, is characterized by the following commonly accepted parameter: $\mathrm{kFD}=100 \times(\mathrm{kfl}-\mathrm{kf} 3) / \mathrm{kfl}[\%]$, where $\mathrm{kfl}$ and $\mathrm{kf3}$ are susceptibilities at frequency fl $(976 \mathrm{~Hz})$ and frequency f3 $(15,616 \mathrm{~Hz})$, respectively.

\subsection{OSL dating}

The chronology of the two layers was determined using the method of Optically Stimulated Luminescence (OSL). The OSL method was applied to six samples which we obtained at five different depths (Tab. 1). These were run in laboratory of Department of Geography, University of Georgia, Athens, USA. A standard procedure was used according to University of Georgia (2016). OSL measurements were carried out using an automated Ris $\emptyset$ TL/OSL-DA-15 reader. Old outlier data were removed in the aliquot age distributions and the ages were recalculated based on the remaining values.

\section{Results}

\subsection{GIS analyses}

One of the main aims of the paper was to declare, that we are dealing with the typical type of the valley, i.e. highland stream valley. The analyses of valley depth in the testing area covering 100 square kilometres (Fig. 3) revealed another 11 similar streams, which are tributaries of small rivers. The river total length in the testing area is 35.5 kilometres (including small rivers) and the common stream mean length is $2.9 \mathrm{~km}$. The valley depth (see Fig. 4) is in case of all detected small streams identical and the depth of such valleys where we might presume also the similar type of sedimentation reaches 45 metres (Fig. 3 and Fig. 4). 


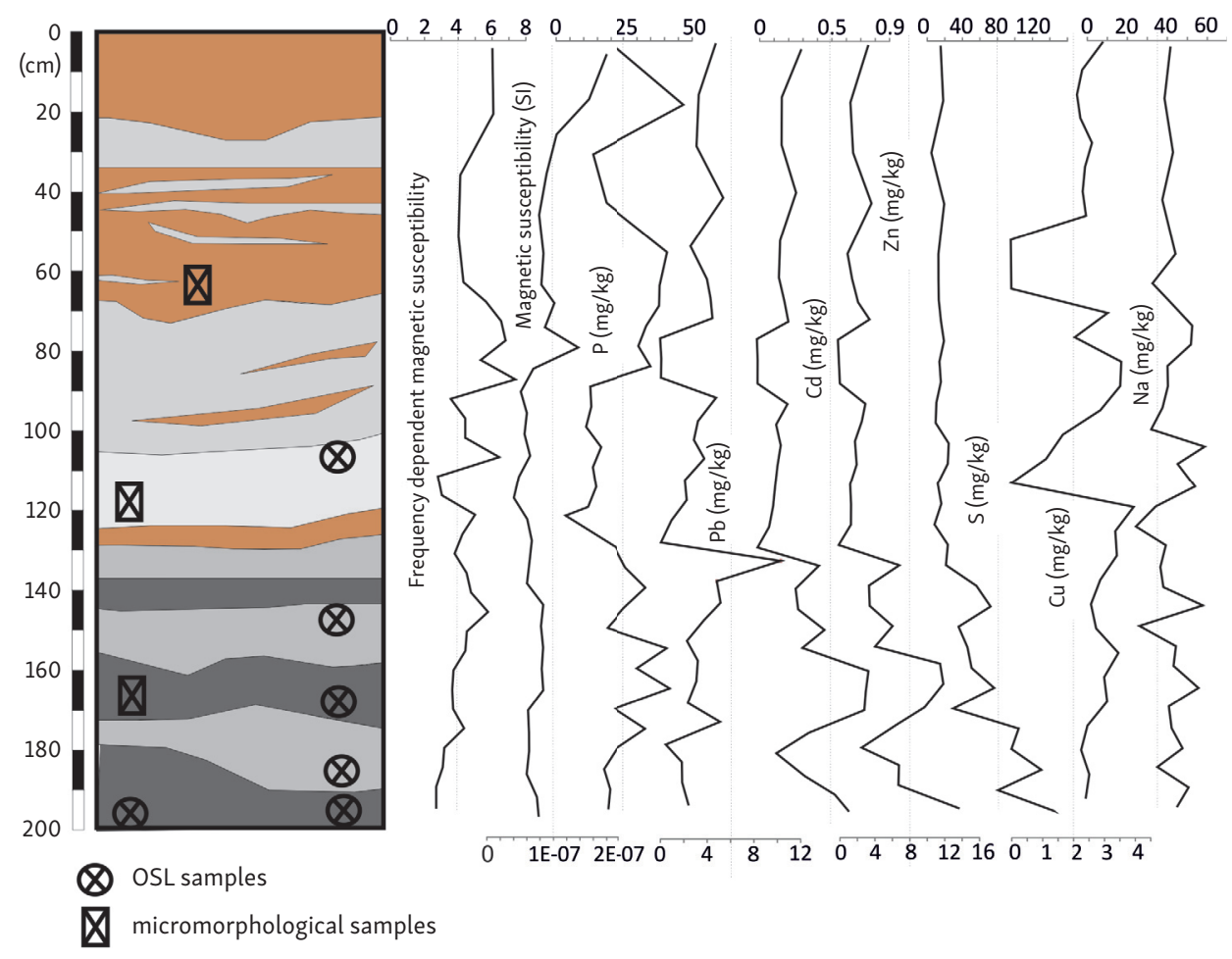

Fig. 5 - Studied sedimentary section, consisting of loams with demonstrated colour changes in lithology and the positions of micromorphological and OSL samples, as well as the magnetic and the geochemical values

The recent history of the testing area was possible to track using the maps of $1^{\text {st }}$ (1763 and 1768), $2^{\text {nd }}(1852)$ and $3^{\text {rd }}(1877)$ Military mapping. Most of the area was in the $18^{\text {th }}$ century covered by non-forest land, which means that it was covered by either pastures or arable land. The western slope of the valley was partly forested. But that fact had been changing at the time - we can easily identify the divide between the two sheets of the First Military Survey by the presence of the forest on the ridge in one sheet only. The river alluvium was narrow back then, but we were not able to determine its width correctly due to inaccuracy of the mapping process. We were able to identify two ponds on the stream. According to the Second Military Survey, the southern half of the valley underwent only minor $(<10 \%$ of surface) changes, whilst the northern part experienced afforestation in surrounding of the Březina stream source. Steep slopes had remained afforested and the floodplain remained very narrow, covered by grassland. Only the southern pond is possible to detect in this stage. The northern one either not existed or was overlaid by the afforested land. The Third Military mapping show only minor changes of 
the land cover and land use $(<5 \%$ of the surface). Also ortophotographs taken in 1953 were studied as well (Fig. 1B). The land cover changes were, again, only minor, especially the extent of afforested area remained same. In this picture we could identify many small fields and/or pastures constituting multifarious land use mosaic. The path/road infrastructure remained almost the same, except new road between Česká Bělá and Cibotín, which is based on former paths as well. Recent ortophotographs from 2014 (Fig. 1C) show expansion of afforested areas. This was caused mainly by enlargement of former forests and by filling the gaps between these, mostly in the northern part of the basin. Only very few, small newly afforested areas appeared. The mosaic of fields and pastures disappeared, or more precisely, the fields and pastures were put together to create large agricultural units. Alluvium is covered mostly by grasslands. Old paths were ploughed up and only major roads were preserved. A new bypass road was built.

\subsection{Sedimentary record and micromorphology}

The studied section (Fig. 2) reached the depth approximately of $200 \mathrm{~cm}$ (Fig. 5). Right side of the river valley is open to the gradual slopes allowing deposition of fine grained weathered material, while the opposite banks are situated in direction to the steep slopes composed of relatively hard rocks. The study section was split in two main horizons divided by lithological change which was followed also by the different oxidation/reduction processes ( $\mathrm{ca} 0-130 \mathrm{~cm}$ and $130-200 \mathrm{~cm}$ ) considering the nature of sediments and their colours. The lower part of the section $(130-200 \mathrm{~cm})$ constitutes of well sorted dark grey/black organic rich silt loam. The colour of these deposits changes from very dark greenish grey (Gley 2 3/1) to greenish grey (Gley $26 / 1$ ). Bands of these colours repeatedly alternate (Fig. 5). There are two reasons for very abrupt upward transition (to layers in the depth $0-130 \mathrm{~cm}$ ). One of them is evident lithological change. The material become coarser and held the level of the temporary ground water. Therefore, the maximum accumulations of Fe oxides are visible in this horizon and are reflected by red colour (2.5YR 4/8). The horizon above $(105-125 \mathrm{~cm})$ is composed of unsorted loam and is obviously illuviated, therefore its colour is light reddish grey (2.5YR 7/1). The material above the depth of $105 \mathrm{~cm}$ has similar lithological properties like layer below, but in some part thin bands are preserved. The colour varies between light grey (7.5YR 7/1) and reddish brown (5YR 5/4). The differences between the bands are not always very clear and the bands differ mainly in the grain size and colour. The increased amount of rock debris was recorded in direction to the upper parts of the section.

The micromorphological samples from the depth of 60 and $120 \mathrm{~cm}$ below the surface revealed to have similar parameters (Fig. 6). They are composed 


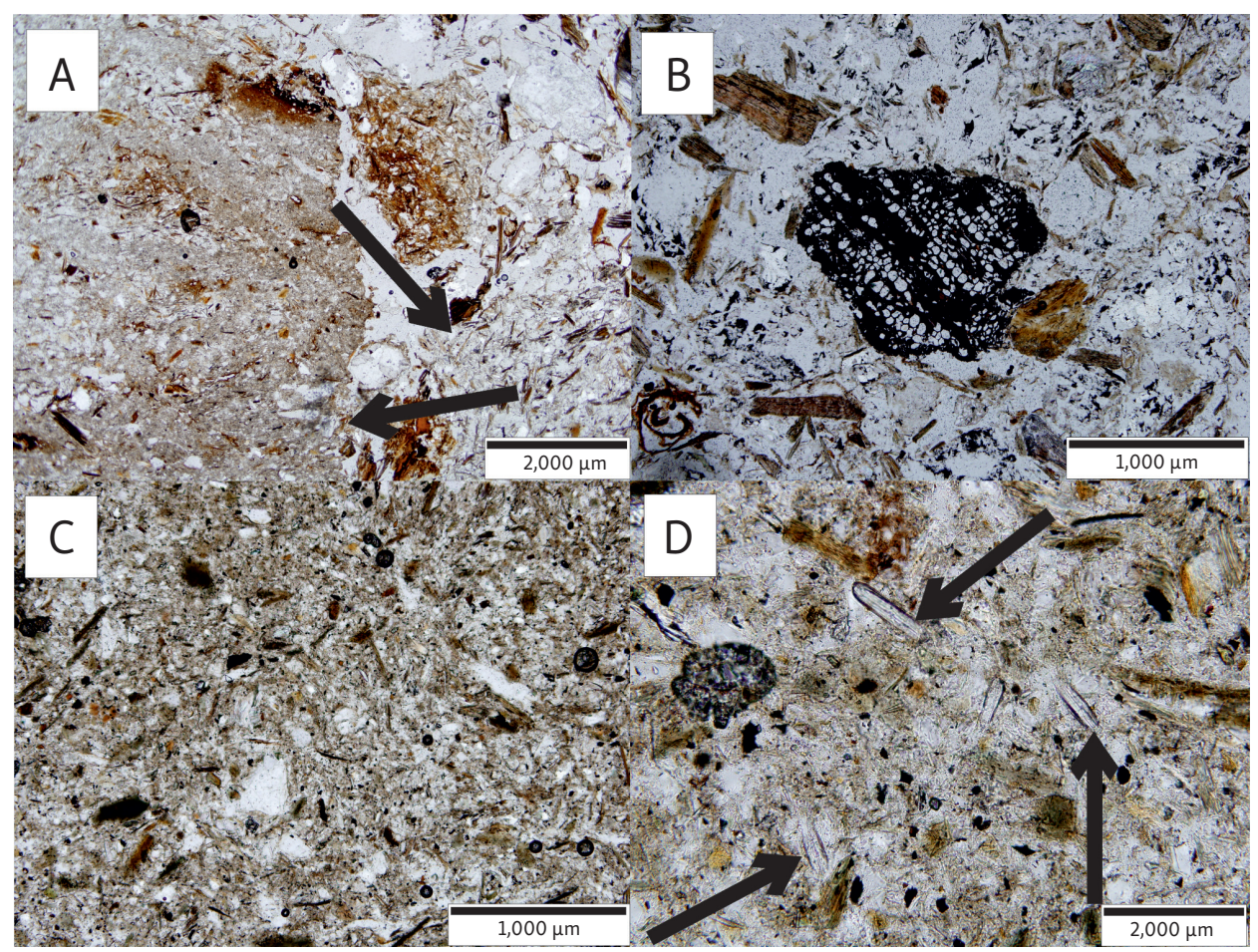

Fig. 6 - Micromorphological photodocumetation of the main identified features. PPL - plane polarised light; A - sample from the depth of $60 \mathrm{~cm}$ is composed of mix of lithologically different matrix (see arrows); B - sample from the depth of $120 \mathrm{~cm}$ is composed of unsorted material and rich or charcoal (centre) as well as of organic matter (left lower corner); C - well sorted loam from the depth of $170 \mathrm{~cm}$, black particles are composed mainly of microcharcoal and decomposed organic matter (PPL); D - arrows pointing to the diatomite (PPL).

of banded horizons of moderately sorted loam and unsorted sandy loam. Both samples have massive to subangular blocky microstructure with prevailing cracks and intergranular types of pores. $C / F_{(500 \mu \mathrm{m})}=5: 95 ; C / F_{(100 \mu \mathrm{m})}=80: 20$. Fine grained bands have $C / F_{(100 \mu m)}=20: 80$. The coarse fraction is composed of angular to subangular quartz, biotite and feldspar. Fragments of metamorphic rocks were observed. Also aggregated of different grain size fractions are typical for observed material. Fine grained fraction is light brown to grey brown (differs according to the changing grain size) with crystalline B fabric. Organic matter is composed of decomposed fine grained part of matrix (humus) and sparse partly decomposed fragments of brown organic matter. Also rare fragments of charcoal were observed. The main pedofeatures are passage features and $\mathrm{FeOH}$ impregnations and hypocoating. These samples have typical signs of colluvial formation processes. 
The micromorphological sample from the depth of $170 \mathrm{~cm}$ differs from samples described above significantly (Fig. 6). The material is well sorted loam with massive microstructure and minimum, mostly intergranular pores. $C / F_{(100 \mu m)}=10: 90$; $\mathrm{C} / \mathrm{F}(50 \mu \mathrm{m})=50: 50$. The coarse fraction is composed of angular to subangular quartz, biotite and feldspar. Typical part of coarse fraction is the appearance of opal diatomite's bodies reflecting stagnant water environment as well as the appearance of phytoliths from decomposed organic matter. Also sand size fraction of charcoal is commonly present. The fine fraction is light grey with crystalline B fabric. Organic matter consists of decomposed fine grained part of matrix (humus) and also by partly decomposed and decomposed fragments of brown organic matter. Fragments of wood were observed as well. Black fragments of organic matter are connected with the black rounded products of bacteria. Passage features are rare, but were identified. Another observed pedofeatures are Mn nodules, rare but present. The presence of non-fragmented diatomite's bodies suggests the stagnant water environment. On the other hand, the elongated biotite crystals are not oriented horizontally, but randomly distributed all over the fine matrix, which probably eliminate the sedimentation in standing water. Such random orientation of biotite crystals more probably reflects the sedimentation of fine grained material in high energy environment, i.e. it seems, we are dealing with redeposited stagnant water deposits.

\subsection{Geochemical and magnetic signal}

Concentrations of the main elements typical for polymetallic ores ( $\mathrm{Zn}, \mathrm{Pb}, \mathrm{Cu}$ and $\mathrm{Cd}$ ) noticeably increase in the lowest parts of the section in depths of about $135-190 \mathrm{~cm}$. Their increased values are rather steadily higher in fine grained sorted sediment detected at the bottom of the section. Na concentrations in the same sediment are of constant nature, however, in the upper layers the increased amount of $\mathrm{Na}$ can be detected as well and therefore its concentrations are probably not

Tab. 1 - OSL primary data in comparison with recalculated data (old outlier data removed, ages recalculated)

\begin{tabular}{lccc}
\hline Lab number & Layer $($ dept in $\mathrm{cm})$ & OSL ages $(\mathrm{ka})$ primary & OSL dates $(\mathrm{ka})$ recalculated \\
\hline UGA14OLS-955 & $1 \mathrm{~L}(195-200 \mathrm{~cm})$ & $0.997 \pm 0.12$ & $0.912 \pm 0.10$ \\
UGA14OLS-956 & $1 \mathrm{R}(195-200 \mathrm{~cm})$ & $0.983 \pm 0.11$ & $0.922 \pm 0.09$ \\
UGA14OLS-954 & $2(185-190 \mathrm{~cm})$ & $2.320 \pm 0.32$ & $1.690 \pm 0.19$ \\
UGA14OLS-958 & $3(165-170 \mathrm{~cm})$ & $1.010 \pm 0.10$ & $0.996 \pm 0.10$ \\
UGA14OLS-959 & $4(145-150 \mathrm{~cm})$ & $1.410 \pm 0.19$ & $1.230 \pm 0.15$ \\
UGA14OLS-966 & $5(105-110 \mathrm{~cm})$ & $0.720 \pm 0.19$ & $0.596 \pm 0.15$ \\
\hline
\end{tabular}


directly related to the ore processing. Increased amounts of elements typical for organic sediments $(\mathrm{P}, \mathrm{S})$ correlate positively with elements typical for polymetallic ores in the lower parts of the section. Magnetic susceptibility values correlate only with an increased content of phosphates in the uppermost part of the profile. The enhancement of magnetic signal is visible only in the case of magnetic susceptibility in the uppermost part of the section. It is a question if connected with ongoing pedogenesis, because the values of frequency magnetic susceptibility is quite low not higher than 6 . The geochemical and magnetic results are presented in the Figure 5.

\subsection{OSL Dating}

Two data obtained by OSL (Table 1) from the depth of $195-200 \mathrm{~cm}$ are quite homogenous and cover the timespan between the $10^{\text {th }}$ and the $11^{\text {th }}$ century. According to the principle of stratigraphy the material deposited above should give the same or younger signal, but the data we obtained show in some cases even older age. The uncertainty of these dates is approximately $10 \%$. To get more exact dates, the older signal caused by insufficient exposure due to the type of transport the outlier signal was removed. In spite of the fact, that the new calculation shows for the depths of $165-170 \mathrm{~cm}$ the similar signal as for the depth of $195-200 \mathrm{~cm}$, there are still two positions giving older signal (positions $185-190 \mathrm{~cm}$ and $145-150 \mathrm{~cm}$ ). The uppermost sample gives slightly younger date corresponding to the $14^{\text {th }}$ century. With respect to the statistical mistakes of OSL dating given by the type of deposition (insufficient exposure) may be said, that the whole lower complex of the study section $(105-200 \mathrm{~cm})$ originated during the timespan between the $11^{\text {th }}$ and the $14^{\text {th }}$ century.

\section{Discussion}

\subsection{Changing geomorphology over the time}

How to track the changing geomorphology of the valley? The information might be taken from the geological and as well as from geomorphological structures. We know that the development of small river valleys is connected with early Holocene climatic changes, when more intensive erosion took a place there (Becker, Schirmer 2008). The first impact on the valley development is usually the appearance of spring connected with the lithological inhomogeneity. This is case in point example of Česká Bělá valley, where western slopes are composed mainly of micaschist and eastern slope is made up of paragneiss/migmatite. This slight change in 
lithology resulted in steeper western slopes in contrast with the gradual eastern slopes of the valley. The main formation process is fluvial and slope erosion. The youngest phase lasted probably from the beginning of Holocene when the abrupt climatic changes caused the high differences in precipitation (Roberts 2014). The considerable geomorphology changes might be also caused by the human presence. The area of Bohemian-Moravian Highlands (including the study area) was intensively explored for polymetallic ores since the Middle Ages. These activities were connected with the expansion of settlements and big towns, but how did they really influenced the landscapes of mining areas? The intensity of change depends on mining practices as well as on the richness of polymetallic sources. We are able to track these changes also in historical sources mainly within the areas of medieval cities (Hrubý et al. 2014). But how did the areas far away these cultural centres look? The main geomorphological features are the most likely mining pits and shafts (Hrubý et al. 2014) as well as relatively thick sedimentary record of settling ponds. Česká Bělá is a typical example of mined area with few still visible mining mounds. On the other hand, these features, still well visible in the landscape, didn't change too much the geomorphology of the valley itself. The main factor changing the morphology during the medieval times in the study area was the deforestation connected with the first intensive human induced erosion. The overview of the human induced soil erosion during medieval times is in detail described by Dotterweich (2013) and fit to the results obtained from study site. For example, Dotterweich and Dreibrodt (2011) declare, that the soil erosion appears to have been one factor in a complex causality spiral leading to socioeconomic instability and land use changes during medieval times. The most remarkable phase of human induced soil erosion took place in the first half of the $14^{\text {th }}$ century a phase of climate deterioration with increasingly frequent extreme precipitation events and very intensive land use (Dotterweich, 2013).

Another story seems to be human influence on the valley morphology during the Modern Age. The intensive agriculture resulted often in intensive erosion. The second well-known intense soil erosion phase with severe gullying developed in the mid-eighteenth to early nineteenth centuries $\mathrm{CE}$. Historical records document extreme precipitation events during these two phases, implying a strong influence of climatic extremes on geomorphological processes (Dotterweich, 2013). The results of human impact in this time at Česká Bělá region are the mudflows or sheetwash of arable land into the valley floor as well as the change of the slope angles. In spite of it was this erosion significantly less intensive than the long term medieval erosion documented in lower parts of the sections (ca $110 \mathrm{~cm}$ and lower). Land-use and land-cover changes identified between The Second and The Third Military Survey do not imply significant changes in floodplain geomorphology. On the other hand, there might be lack of precision in mapping in case of such old type of maps. A significant change took place after the collectivization of agricultural 
land. This process resulted in changes in the landscape mosaic. The individual fields were put together into much larger ones in order to enable mass production, see Figure 1, parts B and C. These large fields allowed erosion rates to raise quickly and to transport excessive amounts of material down the slopes. Even though the recent erosion is significant, the eroded material composes smaller amount of the valley infilling than medieval sediments derived from the ore processing and land use. The Middle Ages erosion is at least of the same importance as the Modern times one. See Table 1 with OSL dating, where sediment at $1 \mathrm{~m}$ depth is dated to the $14^{\text {th }}$ century. This is also supported by Dotterweich (2013) who states that the main erosion was in the $14^{\text {th }}$ century, so the latest $14^{\text {th }}$ century sediments may have been buried less than $1 \mathrm{~m}$ deep. Another possible human impact influencing the geomorphology of streams and rivers is the channel and flow rate regulation. This is usually implemented just in an area settled by humans or used for other waterworks, which is not the example of presented case study, but the similar case study was described for example by Treml et al. (2008).

\subsection{Information value of sedimentary archives}

The bottoms of the small streams of mountain or highland areas are composed mainly of moderately sorted pebbles (Milliman, Syvitski 1992; Růžičková et al. 2002). The fine-grained deposits lack usually mainly within the first hundreds of metres of the stream valley due to short transport; pebble size is the most typical for the transported material. Březina stream valley in Česká Bělá area is a typical example. Therefore, the most typical feature of these highland stream valleys is the lack of the well readable environmental record. If there is any sedimentary record within the inundation zone available, it is usually connected with the human presence. Such sediments appear in highland landscapes of the BohemianMoravian Highlands since medieval period in context of mining and agricultural activities. We are usually able to track them geochemically (Hrubý et al. 2014). These deposits are typical by the increased amount of elements like $\mathrm{Au}, \mathrm{Ag}, \mathrm{Pb}$, $\mathrm{Zn}, \mathrm{Cd}, \mathrm{Cu}$, etc. (Horák, Hejcman 2013). The amount of these metals also depends on the type of processing which varied during the time (Hrubý et al. 2014). The fine grained organic rich sediment explored in Březina stream alluvia revealed increased amount of elements we expected in polymetallic ores $(\mathrm{Zn}, \mathrm{Pb}, \mathrm{Cu}$ and $\mathrm{Cd}$ ). According to Hrubý et al. (2014) the state of mining activities recorded in the Bohemian-Moravian Highlands corresponds to the third and fourth phase of mining activities recorded in similar mining area in Hartz. These phases are typical by already complex and intensive mining activities which were common during $12^{\text {th }}-13^{\text {th }}$ century (Alper 1998, 2008). Whilst primary OSL dates measured in Březina locality vary a lot, recalculated OSL dates show very similar ages except 
samples UGA14OSL-954 and UGA14OSL-959, and except the topmost sample UGA14OSL- 966 form the depth of $105-110 \mathrm{~cm}$. Based on the results, the section dated by the OSL, therefore contains sedimentary archive from both the Middle ages and Modern times, and therefore the beginning of mining activities in the Bohemian-Moravian Highlands, recorded in the area of Brezina basin, should be set into the beginning of $11^{\text {th }}$ century, which is much earlier than supposed generally. The results of OSL dating of Březina section are also supported by one $\mathrm{C}^{14}$ date (1016-1155 cal.) provided by Hrubý et al. (2014).

The earliest intensive mining activities in the area of Central Europe are known from Eneolithic period from Austrian Alps. The medieval mining is the most intensive there during $13^{\text {th }}$ century (Krause 2003). Alper $(1998,2008)$ describe for the Hartz area two earlier phases of mining activities. The first one dates to $7^{\text {th }}-10^{\text {th }}$ century and it is typical by the change of landscape vegetation and the production of slag. The second phase is typical by the increase of iron mils. Such relatively young ore mining and processing is known also for example from Schwarzwald (Black Forrest) area and detected already since $10^{\text {th }}-11^{\text {th }}$ century (Wagner 2008, Steuer 2003) whilst for example in the area of Erzgebirge a Erzgebirgsvorland are the mining activities documented from the $13^{\text {th }}$ century (Schwabenicky 2009). We believe that the timespan of the origin of sedimentary record in Březina covers minimally the second phase of mining activities described by Alper $(1998,2008)$.

The $\mathrm{Au}$ and $\mathrm{Ag}$ were not detected in case of Březina alluvia, but the reason is probably just the methodological identification of these elements, because we only measured forms of potentially plant accessible elements. Hrubý et al. (2014) detected in the same type of sediment at locality Brezina stream the high increase of $\mathrm{Pb}, \mathrm{As}, \mathrm{Sb}, \mathrm{Cu}, \mathrm{Zn}, \mathrm{Ag}, \mathrm{Cd}$, and $\mathrm{Au}$. The less mobile elements As, Sb, Ag, Cd and $\mathrm{Au}$ are quite rare in surrounding rocks and their presence corresponds with the mining. The elements $\mathrm{Pb}, \mathrm{Cu}$ and $\mathrm{Zn}$ are more mobile and therefore their presence in studied sediments might be higher also due to the longer transport, but they are also derived from background by the mining activities. These contaminants were transferred through the river system and accumulated on floodplains, which function as contaminant sinks (Marron 1992). Contaminants may remain within the fluvial system for a long period of time, even after the original source of contamination no longer exists (Hofmann et al 2010).

Archaeologists had previously found at the bottom of sedimentary record discussed in this paper a cut fir board (few decimetres downstream), most likely not in-situ, which they believe to be an evidence of ore washing (Hrubý et al. 2014). Our micromorphological observations as well as geochemical signal revealed, that in this case we are dealing with the redeposited material of settling pit. The water environment is documented by high amount of diatomites and increased amount of organic matter as well as phosphorus and enhanced values of magnetic susceptibility. These small valleys probably didn't have strong barriers and high rainfalls 
or just the age of the barrier may cause its destruction and further redeposition of its infilling down to the stream.

Calibrated AMS radiocarbon dating of the last annual ring of fir board found previously by archaeologists within this type of sediment shows that it most likely belongs to the period between 1016 and 1155 AD (Hrubý et al. 2014). The OSL dates sampled right above this fine grained organic sediment provided similar (even slightly older) dates which would suggest that it could be the oldest evidence of mining in the Bohemian-Moravian highlands.

The rest of observed sedimentary record revealed by its composition and textural features the different formation processes which took place probably much later. The OSL dating of the sample corresponding with the beginning of this sedimentation, might be set approximately into the $14^{\text {th }}$ century or later as discussed above. We can speak very likely about young runoff sediments linked to the intensive agriculture use of surrounding slopes. The results are then the income of unsorted deposits into the bottom of the valley in state of sheetwash deposits interchanged with mudflow deposits. According to the known analogies (Dotterweich 2013) this type of erosion is massive in the last 150 years. Geochemical record showing low contents of heavy metals compared to deeper part of the section and increased contents of phosphorus indicates agricultural activities. Also increased values of magnetic susceptibility corresponding to deposited soil indicate material of agricultural soil erosion. In terms of the sedimentology upper parts of the section are represented by alternating thin layers of soil runoffs of different grain size due to different energy of sedimentation during the hydrometeorological event. This sedimentological record corresponds to similar known sections from the Bohemian-Moravian Highlands (Jeleček 1999), where increased erosion of agricultural soil was manifested especially in the second half of the $20^{\text {th }}$ century, the period of intensive socialist agriculture characterized by usage of heavy machinery.

\section{Conclusions}

The analyses of the valley depth in the testing area covering 100 square kilometres show, that the morphometry of small streams valleys in highlands has very similar parameters. In total 11 similar streams which are tributaries of small rivers were revealed there. The total river length in the testing area is 35.5 kilometres (including small rivers) and the river mean length is $2.9 \mathrm{~km}$. The Březina stream river morphology is typical for the study area.

The Medieval and Modern time history of the area may be read from the preserved floodplain record represented by 2 metres thick alluvium with contribution of colluvial deposits from adjacent slopes. Two main divided horizons reflect two 
main phases of fluvial activity and sheet erosion. The more intensive erosion was recorded for the Medieval Times, starting already in $11^{\text {th }}$ century and lasting approximately up to $14^{\text {th }}$ century. It corresponds to the phase of climate deterioration with increasingly frequent extreme precipitation events and very intensive land use. The surprising is appearance of mining activities in this area already in $11^{\text {th }}$ century, because it was trusted, that the mining activities started much later there. The medieval anthropogenic impact was also detected not only by mining and ore processing-related sediments in recent alluvium, but also by presence of mining landforms on sites of ore mineralisation.

Continuing sediment accretion in the floodplain deposits caused valley morphology changes, which were identified by various sedimentological, micromorphological, geochemical and magnetic analyses. The deposits formed by the sheetwash erosion interchanged with mudflow deposition infills the bottom of the valley and overlies older sediments. The impact is also apparent from analyses of the maps of Military mapping and recent ortophotographs. The human impact is not visible only as the geomorphological changes, but also as heavy metal pollution in the bottom of the valley infilling and as ongoing soil erosion of the valley slopes. The soil erosion and use of phosphate fertiliser resulting into the appearance of ruderal species in the valley seems to be the most typical human impact during the Modern times.

\section{References}

ALPER, G. (1998): Mittelalterliche Blei/Silberverhütung beim Johanneser Kurhaus, ClausthalZellerfeld (Harz). Nachrichten aus Niedersachsens Urgeschichte, 67, 87-134.

ALPER, G. (2008): The Eastern Harz Mountains during the Middle Ages - the Impact of Mining and Metal Production. In: Cultural heritage and landscapes in Europe - Landschaften: kulturelles Erbe in Europa, Bartels C., Küpper-Eichas C. (eds): Proceedings of the International Conference, Bochum, 467-488.

ANDERSON, R.S., ANDERSON, P.A. (2010): Geomorphology: The Mechanics and Chemistry of Landscapes. Cambridge University Press, $1^{\text {st }}$ edition, Cambridge.

BECKER, B., SCHIRMER, B. (2008): Palaeoecoogical study on the Holocene valley development of the River Main, Southern Germany. Boreas, 6, 4, 303-321.

BERNARD, J.H. (1991) Empirical types of ore mineralization in the Bohemian Massif. ÚUG, Praha.

DEARING, J.A., JONES, R.T. (2003): Coupling temporal and spatial dimensions of global sediment flux through lake and marine records. Global and Planetary Change, 39, 1-2, 147-168.

DOTTERWEICH, M. (2008): The history of soil erosion and fluvial deposits in small catchments of central Europe: Deciphering the long-term interaction between humans and the environment - A review. Geomorphology, 101, 192-208.

DOTTERWEICH, M. (2013): The history of human-induced soil erosion: Geomorphic legacies, early descriptions and research, and the development of soil conservation - A global synopsis. Geomorphology, 201, 1-34. 
DOTTERWEICH, M., DREIBRODT, S. (2011): Past land use and soil erosion processes in central Europe. PAGES news 19, 2, 49-51.

ESRI (2012): Using the Topo to Raster Tool. In: ArcGIS Desktop 9.3 Help. Available at http:// webhelp.esri.com/arcgisdesktop/9.3/ (10.4.2015).

DIBAVOD (2016): Czech Water Network, http://www.dibavod.cz/ (15.10.2015).

GRYGAR, T., SVĚTLÍK, I., LISÁ, L., KOPTÍKOVÁ, L., BAJER, A., WRAY, D.S., ETTLER, V., MIHALJEVIČ, M., NOVÁKOVÁ, T., KOUBOVÁ, M., NOVÁK, J., MÁČKA, Z., SMETANA, M. (2010): Geochemical tool for the stratigraphic correlation of floodplain deposits of the Morava River in Strážnické Pomoraví, Czech Republic from the last millennium. Catena, 80, 2, 106-121.

HOFFMANN, T., THORNDYCRAFT, V.R., BROWN, A.G., COULTHARD, T.J., DAMNATI, B., KALE, V.S., MIDDELKOOP, H., NOTEBAERT, B., WALLING, D.E. (2010): Human impact on fluvial regimes and sediment flux during the Holocene: Review and future research agenda. Global and Planetary Change, 72, 3, 87-98.

HORÁK, J., HEJCMAN, M. (2013): Use of Trace Elements from Historical Mining for Alluvial Sediment Dating. Soil \& Water Research, 8, 2, 77-86.

HRUBÝ, P., HEJHAL, P., MALÝ, K., KOČÁR, P., PETR, L. (2014): Centrální Českomoravská vrchovina na prahu vrcholného středověku. Archeologie, geochemie a rozbory sedimentárních výplní niv. Masaryk University, Brno.

JELEČEK, L. (1999): Proměny krajiny a půdní fond Česka. Geografické rozhledy, 8, 98-99.

JENČO, M., PACINA, J., SHARRY, P. (2009): Terrains skeleton and local morphometric variables: geosciences and computer vision technique. In: Advances in Geoinformation Technologies. Technical University of Ostrava, Ostrava, 57-76.

KALICKI, T., NOWAK, M. (2014): Natural and Anthropogenic Changes in the environment in the Middle Ondava Basin (Eastern Slovakia) during the Neolithic Period. Interdisciplinaria Archaeologica: Natural Sciences in Archaeology, 5, 2, 119-130.

KRAUSE, R. (2003): Settlement archaeology and prehistoric mining: a new interdisciplinary research project in the Alpine valley Montafon in Vorarlberg (Austria). Prehistoria Alpina, 39, 201-218.

Ǩ̌ǏŽEK, M. (2007): Údolní niva jako geomorfologický fenomén. In: Langhammer, J. (ed.): Povodně a změny v krajině. Faculty of Science, Charles Univeristy, Prague, 217-229.

LEWIN, J. (2008): Medieval environmental impacts and feedbacks: The lowland floodplains of England and Wales. Geoarchaeology, 25, 3, 267-311.

LÜNING, J. (1996): Anfänge und frühe Entwicklung der Landwirtschaft im Neolitikum (5500-2200 v. Chr.). In: Lüning, J. et al. (eds): Deutsche Agrargeschichte, Vor- und Frühgeschichte. Ulmer, 15-139.

MACKLIN, M.G., BENITO, G., GREGORY, K.J., JOHNSTONE, E., LEWIN, J., MICHCZYŃSKA, D.J., SOJA, R., STARKEL, J., THORNDYCRAFT, V.R. (2006): Past hydrological events reflected in the Holocene fluvial record of Europe. Catena, 66, 1-2, 145-154.

MACKLIN, M.G., LEWIN, J., JONES, A.F. (2014): Anthropogenic alluvium: An evidence-based meta-analysis for the UK Holocene. Anthropocene, 6, 26-38.

MALÝ, K. (1998): Současný stav lokalit starého dolování v okolí Stříbrných Hor u Havlíčkova Brodu. Vlastivědný sborník Vysočiny, odd. věd společenských. 11, 48-85.

MILLIMAN, J.D., SYVITSKI, J.P.M. (1992): Geomorphic/Tectonic Control of Sediment Discharge to the Ocean: The Importance of Small Mountainous Rivers. The Journal of Geology, $100,5,525-544$.

MARRON, D.C. (1992): Floodplain storage of mine tailings in the Belle Fourche river system: a sediment budget approach. Earth Surface Processes and Landforms, 17, 675-685. 
MATYS GRYGAR, T., ELZNICOVÁ, J., TŮMOVÁ, Š., FAMĚRA, M., BALOGH, M., KISS, T. (2015): Floodplain architecture of an actively meandering river (the Ploučnice River, the Czech Republic) as revealed by the distribution of pollution and electrical resistivity tomography. Geomorphology, 254, 41-56.

MESSERLI, B., GROSJEAN, M., HOFER, T., NÚÑEZ, L., PFISTER, C. (2000): From naturedominated to human-dominated environmental changes. Quaternary Science Reviews, 19, $1-5,459-479$.

MINÁR, J., JENČO, M., EVANS, I.S., MINÁR, J. JR., KADLEC, M., KRCHO, J., PACINA, J., BURIAN, L., BENOVÁ, A. (2013): Third-order geomorphometric variables (derivatives): definition, computation and utilization of changes of curvatures. International Journal of Geographical Information Science, 27, 7, 1381-1402.

PARMA, D., VEJROSTOVÁ, L., LISÁ, L., BAJER A., PACINA J., GOTTVALD, Z. (2015): Neolithic Occupation of Svratka Alluvial Plain; Case Study from Brno-Přízřenice, Czech Republic. Interdisciplinaria Archaeologica, 6, 2, 181-193.

MOL, J., VANDENBERGH, J., KASSE, C. (2000): River response to variations of periglacial climate in mid-latitude Europe. Geomorphology, 33, 3-4, 131-148.

MUNSELL, A.H. (2000): Munsell soil color charts. Munsell Color.

NOVÁKOVÁ, T., KOTKOVÁ, K., ELZNICOVÁ, J., STRNAD, L., ENGEL, Z., GRYGAR MATYS, T. (2015): Pollutant dispersal and stability in a severely polluted floodplain: A case study in the Litavka River, Czech Republic. Journal of Geochemical Exploration, 156, 131-144.

ROBERTS, N. (2014): The Holocene: An environmental history, Willey Blackwell. Oxford.

RŮŽIČKOVÁ, E., RŮŽIČKA, M., ZEMAN, A., KADLEC, J. (2001): Quaternary clastic sediments of the Czech Republic. Textures and structures of the main genetic types. Czech Geol. Sur.

SCHWABENICKY, W. (2009): Der mittelalterliche Bergbau im Erzgebirgsvorland und im westlichen Erzgebirge. Chemnitz.

STEUER, H. (2003): Montanarchäologie im Südschwarzwald. Ergebnisse aus 15 Jahren interdisziplinärer Forschung. Zeitschrift für Archäologie des Mittelalters, 31, 175-219.

STOOPS, G. (2003): Guidelines for Analyses and Descriptions of Soil and Regolith Thin Sections. Science Society of America, Madison WI.

TREML, V., KŘÍŽEK, M., ENGEL, Z., ČERMÁK, P. (2008): Dynamika údolní nivy na př́́kladu Cikánského potoka (povodí Blanice) a Jeleního potoka (povodí Opavy). In: Langhammer, J. (ed.): Údolní niva jako prostor ovlivňující průběh a následky povodní. Faculty of Science, Charles University, Prague, 229-243.

UNIVERSITY OF GEORGIA (2016): The technique of OSL dating, http://osl.uga.edu/technique. html (12.11.2015).

WAGNER, H. (2008): Auf der Spur des Silbers - 750 Jahre Prinzbach, Gerolgsecker Land. Jahrbuch einer Landschaft 50 „Gold, Silber, Edelstein“, 45-72.

WILLIAMS, M. (2003): Deforesting the Earth: From Prehistory to Global Crisis. The University of Chicago Press, London. 


\section{SHRNUTÍ}

\section{Zhodnocení antropogenního vlivu na geomorfologii údolí drobných vodních toků vrchovin: př́ípadová studie z Českomoravské vrchoviny, Česko}

Formační procesy malých vodních toků a vliv člověka na jejich sedimentární archivy např́klad v kontextu těžebních aktivit lze studovat prostřednictvím GIS, sedimentologie a prostorových i vertikálních geochemických charakteristik. Případová studie údolí potoka Březina na Českomoravské vrchovině představuje dynamický vývoj malého údolí v průběhu posledních století. Díky své geomorfologii, litologii výplně údolního dna a zdokumentovaným středověkým těžebním aktivitám lze na této lokalitě studovat možnou míru antropogenního impaktu na vývoj současné krajiny. V předkládaném článku je zhodnocena informační hodnota sedimentárního záznamu výplně údolního dna a na to navazující geomorfologický vývoj krajiny ve vztahu k antropogenním aktivitám.

Analýzy hloubky údolí v zájmovém území o rozloze 100 km² ukazují, že jednotlivá říční údolí vrchoviny jsou si navzájem morfometricky velmi podobná. Analýza na základě dat z DMT 1:25 000 a dat z databáze DIBAVOD odhalila celkem 11 podobných drobných vodních toků, které jsou přítoky menších řek. Celková délka vodních toků v území je 35,5 km (vč. menších řek) a průměrná délka vodního toku je $2,9 \mathrm{~km}$. Potok Březina a jeho údolí tak lze označit jako typické pro danou oblast.

Celková mocnost výplně údolního dna je v místě vybrané sondy 2 metry, v údolí mocnost výplně kolísá od několika cm po $3 \mathrm{~m}$ (určeno na základě terénního průzkumu). Sonda je umístěna ve spodní části údolí na pravém břehu potoka Březina. Kromě klasického sedimentologického popisu a barevné identifikace podle Munsellovy škály byly provedeny i mikromorfologické analýzy sedimentu, analýzy Mehlich III (P, K, Ca, Mg, Zn, Cu, Cd a Pb), analýzy magnetické susceptibility (hmotnostní i frekvenčně závislá magnetická susceptibilita). Sedimentární záznam byl datován metodou opticky stimulované luminiscence.

Výplň údolního dna se skládá ze dvou hlavních litologických jednotek, které obsahují informace o středověké těžbě a následného zpracovávání rudy a také o současných zemědělských aktivitách. Hlavní vyčleněné sedimentární horizonty tak reprezentují dvě hlavní fáze vývoje údolí: aluviální (povodňovou) aktivitu a plošnou erozi (ron, bahnotok). Intenzivnější eroze byla zaznamenána ve středověku, se začátkem již v 11. století a trvající přibližně do 14. století. Toto období koresponduje s fází zhoršení klimatu spojenou s nárůstem frekvence extrémních srážkových událostí a velmi intenzivním využitím krajiny. Jako překvapivá se zde jeví přítomnost těžebních aktivit již v 11. století, protože obecně se předpokládá na základě historických pramenů, že tyto aktivity zde probíhaly až později (cca od 14. století). Sedimenty spojené s těžbou a zpracováním byly zachyceny ve formě jemnozrnných organických sedimentů (pravděpodobně redeponovaných výplní původně odkalovacích nádrží), které byly bohaté na diatomity a zároveň na těžké kovy. Středověké antropogenní aktivity nejsou doloženy pouze sedimenty spojenými s těžbou a zpracováním kovů v současném prostoru aluvia, ale i těžebními tvary v místech rudní mineralizace. Postupné narůstání mocnosti sedimentární výplně údolí způsobilo změnu jeho morfologických charakteristik, které byly zachyceny pomocí různých sedimentologických, mikromorfologických, geochemických a statistických analýz. Dno údolí bylo později vyplněno materiálem pocházejícím z plošných splachů z okolních svahů, které překryly starší sedimenty. Vliv člověka je zřejmý i z map I. až III. vojenského mapování a leteckých snímků z 20. a 21. století. Nejen geomorfologické změny jsou však důkazem činnosti člověka a jeho vlivu na vývoj údolí; identifikována i kontaminace těžkými kovy na dně výplně údolí a pokračující plošná eroze 
na údolních svazích. Půdní eroze a používání fosfátových hnojiv vedoucí k výskytu ruderálních druhů v údolí se zdá být nejtypičtějším dopadem novodobé činnosti člověka.

Obr. 1 Pozice potoka Březina u České Bělé (Českomoravská vrchovina, Česko). A - mapa III. vojenského mapování z roku 1877, B - letecký snímek z roku 1953, C - letecký snímek z roku 2015. Legenda (shora dolů): místo výzkumu; hlavní silnice; vodní toky; orná půda; les; plocha odkryvu pro rychlostní silnici; zástavba; vodní plochy; trvalé travní porosty.

Obr. 2 Zkoumané území s relikty po těžbě (tmavě žlutá) a sondou (světle žlutá).

Obr. 3 Hloubka údolí na území $100 \mathrm{~km}^{2}$ na podkladě nadmořské výšky a hydrologických dat (DIBAVOD). Př́ičné řezy údolími drobných vodních toků jsou znázorněny za účelem ukázání reprezentativnosti studovaného údolí. V legendě: méně než $25 \mathrm{~m}$; 25-35 m; 35-45 m; 45-55 m; 55-75 m; vrcholy; sonda; zájmové území.

Obr. 4 Hloubka údolí byla počítána jako rozdíl mezi nadmořskou výškou dna údolí a spojnicí hřbetů vymezujících údolí.

Obr. 5 Sedimentární záznam skládající se z hlín s barevně reprezentovanými rozdíly v litologii a místy odběru vzorků pro mikromorfologické analýzy, OSL datování a také analýzy magnetické susceptibility a geochemického složení.

Obr. 6 Fotodokumentace hlavních identifikovaných strukturních prvků v mikromorfologické analýze; PPL - světlo procházející jedním nikolem, A - vzorek z hloubky $60 \mathrm{~cm}$ se skládá ze směsice litologicky velmi rozdílné matrix (viz šipky), B - vzorek z hloubky $120 \mathrm{~cm}$ se skládá z nevytř́íděného materiálu a velkého množství uhlíků (střed) a také organické h moty (levý dolní roh), C - dobře vytř́iděná hlína z hloubky $170 \mathrm{~cm}$; černé částice se skládají zejména z mikrouhlíků a rozložené organické hmoty, D - šipky označují diatomit.

\section{ACKNOWLEDGEMENTS}

The paper was supported by the NAKI project "Historical land use of the Bohemian-Moravian Upland in Prehistory and Middle Ages", DF13P01OVV005. The authors also thank to Marek Havlíček for important comments to the GIS analyses. 